\title{
PENGARUH PIJAT OKSITOSIN TERHADAP WAKTU PENGELUARAN KOLOSTRUM IBU POST PARTUM SECTIO CAESARIA
}

\author{
Rezza Fahlilani Zamzara, Dwi Ernawati, Ari Susanti \\ Stikes Hang Tuah Surabaya, Jl. Gadung No 1 Surabaya \\ Email: ernadwi_80@yahoo.co.id
}

\begin{abstract}
The Effect Of Oxytocin Massage Towards The Colostrum Time Release To Post Partum Sectio Secaria Breast-Feeding Mother. Background: Early time release of breast milk is an important to support exsclusive breast feeding. Distribution of colostrum in post partum sectio caesar mother is slower. Objectives: Determine the influence of oxytocin massage on time release of colostrum on post partum sectio caesar mother in Marine Hospital Ewa Pangalila Surabaya. Methods: This study used quasi experiment. Population of this study was mother post sectio caesar with sample consisted of 20 people. The sampling technique used simple random sampling. Instrument used is SOP oxytocin massage and observation task time release of colostrum. The data were analysed with wilcoxon test. Results: time release of colostrum in control group largely $>48$ hour and time release of colostrum in intervention group largely $<24 \mathrm{jam}$, the result based from statistic analysis score $p=0,026<\alpha=0,05$. Showed if any influence of oxytocin massage on time release of colostrum on post sectio caesar mother. Conclusions and Suggestion: The implication of this study is Oxytocin massage affect on spending release of colostrum, The hospital can be apply SOP Oxytocin massage which should be do it in 12 first hours post partum.
\end{abstract}

Abstrak: Pengaruh Pijat Oksitosin Terhadap Waktu Pengeluaran Kolostrum Ibu
Post Partum Sectio Caesar. Latar belakang: Pengeluaran ASI dini adalah syarat dalam
pemberian ASI eksklusif. Pengeluaran kolostrum ibu post partum sectio caesar lebih
lambat. Tujuan: Mengetahui pengaruh pijat oksitosin terhadap waktu pengeluaran
kolostrum ibu post partum sectio caesar. Metode: Penelitian ini menggunakan quasi
experiment. Populasinya adalah ibu-ibu post partum sectio caesar yang berjumlah 20
orang. Teknik sampel menggunakan simple random sampling. Instrumen dengan SPO pijat
oksitosin dan lembar observasi waktu pengeluaran kolostrum. Data dianalisis dengan uji
wilcoxon. Hasil: Waktu pengeluaran kolostrum pada kelompok kontrol sebagian besar
$>48$ jam dan waktu pengeluaran kolostrum pada kelompok perlakuan sebagian besar $<24$
jam, hasil analisis statistik nilai $\mathrm{p}=0,026<\alpha=0,05$ menunjukkan adanya pengaruh pijat
oksitosin terhadap waktu pengeluaran kolostrum pada ibu post partum sectio caesar. Simpulan dan saran: Implikasi penelitian adalah pijat oksitosin mempengaruhi kecepatan pengeluaran kolostrum, sehingga rumah sakit dapat mengaplikasikan SPO pijat oksitosin yang sebaiknya dilakukan pada 12 jam pertama post partum.

Kata Kunci : Pijat Oksitosin, Waktu Pengeluaran Kolostrum, Post Partum Sectio Caesaria 


\section{PENDAHULUAN}

Air Susu Ibu (ASI) merupakan makanan yang terbaik dan yang paling ideal untuk bayi, karena ASI mengandung semua zat gizi yang diperlukan dalam jumlah dan pertimbangan yang tepat ${ }^{1}$. Kolostrum merupakan cairan vicous yang kental dengan warna kekuningan yang keluar dari payudara pada beberapa jam pertama kehidupan yang mengandung kaya akan sekretori immunoglobulin A (Ig A) yang mengandung zat kekebalan tubuh untuk melindungi bayi dari berbagai penyakit infeksi terutama diare ${ }^{2}$.Menurut World Health Organitation (selanjutnya disebut WHO), ASI eksklusif adalah pemberian ASI saja tanpa tambahan cairan lain baik susu formula, air putih, air jeruk, atau makanan tambahan lain sebelum mencapai usia enam bulan ${ }^{3}$.

Sectio Caesarea adalah suatu tindakan yang dilakukan dengan tujuan untuk melahirkan bayi melalui sayatan pada dinding rahim yang masih utuh untuk menyelamatkan nyawa ibu dan bayi ${ }^{4}$. Pada beberapa keadaan persalinan diperlukan tindakan sectio caesar. Persalinan dengan cara ini dapat menimbulkan masalah menyusui terhadap ibu dan bayi ${ }^{5}$. Ibu yang menjalani bedah caesar mungkin belum mengeluarkan ASI nya dalam 24 jam pertama setelah melahirkan, kadangkala perlu waktu hingga 48 jam walaupun demikian bayi tetap dianjurkan untuk dilekatkan pada payudara ibu untuk membantu merangsang pengeluaran ASI pertama ${ }^{6}$. Keterlambatan pengeluaran kolostrum pada ibu sectio caesar disebabkan karena timbulnya nyeri post partum yang secara fisiologis dapat menghambat pengeluaran hormon oksitosin yang sangat berperan dalam proses laktasi. Angka Kematian Bayi (AKB) merupakan salah satu indikator penting menentukan tingkat kecukupan pemberian kolostrum pada bayi baru lahir. Hasil SDKI tahun 2007 melaporkan AKB di indonesia adalah 34 per 1.000 kelahiran hidup. Kendati terus mengalami penurunan, $\mathrm{AKB}$ di indonesia masih jauh lebih tinggi jika dibandingkan negara anggota ASEAN lainnya, AKB di singapura yaitu 3 per 1.000 kelahiran hidup, Brunei Darussalam 8 per 1.000 , Malaysia 10 per 1.000 , Vietnam 18 per 1.000 dan Thailand 20 per $1.000^{7}$. Proporsi penyebab kejadian bayi usia 0-11 bulan yang tertinggi adalah karena diare yaitu sebesar $42 \%^{8}$.

Menurut UNICEF, cakupan ratarata ASI ekslusif di dunia yaitu $38 \%{ }^{2}$. Berdasarkan survei demografi dan kesehatan Indonesia pada tahun 1997 dan 2003, diketahui bahwa angka pemberian ASI eksklusif turun dari $49 \%$ menjadi $39 \%$, sedangkan penggunaan susu formula meningkat tiga kali lipat ${ }^{9}$. Hasil laporan RISKESDA pada tahun 2010 menunjukkan peningkatan pemberian ASI ekslusif untuk bayi berusia $<6$ bulan dilaporkan kurang dari $40 \%$, hasil analisis menunjukkan dari jumlah total bayi usia 0 6 bulan yang mendapatkan ASI ekslusif sebanyak 1.348.532, sedangkan sebanyak 1.134.952 bayi tidak mendapatkan ASI eksklusif. Di Provinsi Jawa Timur sebesar 102.960 bayi tidak mendapatkan ASI ekslusif. WHO memperkirakan bahwa angka persalinan dengan sectio caesarea sekitar $10 \%$ sampai $15 \%$ dari semua proses persalinan di negara berkembang, diantaranya 20\% Britania Raya, 23\% 
Amerika Serikat dan Kanada pada tahun 2003 sebesar $21 \%^{10}$. Berdasarkan studi pendahuluan data awal yang diperoleh dari Rumkitmar Ewa Pangalila Suarabaya jumlah kasus sectio caesar tahun 2014 sebanyak 260 kasus dan pada 3 bulan terakhir di tahun 2015 terdapat sebanyak 64 kasus persalinan ibu dengan sectio caesar .

Ibu melahirkan dengan sectio caesarea mengalami hambatan dalam waktu pengeluaran kolostrum karena beberapa hal, selain kadar hormon prolaktin dan oksitosin yang dapat mempengaruhi pengeluaran kolostrum pada ibu adalah penggunaan obat-obatan saat dilakukan operasi sectio caesarea ${ }^{11}$. Obat-obatan yang diberikan pada saat operasi sectio caesarea digunakan untuk mengurangi rasa nyeri pada saat operasi, namun setelah operasi selesai nyeri yang timbul akibat efek yang hilang dari obat bius dapat mempengaruhi ibu dalam memberikan perawatan pada bayi, sehingga dapat menyebabkan ibu menunda untuk menyusui dan menimbulkan keterlambatan dalam pengeluaran kolostrum. Hambatan menyusui yang terjadi pada ibu post partum sectio caesarea disebabkan karena nyeri post operasi yang mengganggu kenyamanan ibu dapat menghambat kerja saraf glandula pituitari posterior yang menghasilkan hormon oksitosin yang berperan dalam proses laktasi ${ }^{12}$. Intervensi yang dapat dilakukan untuk membantu meningkatkan pengeluaran kolostrum pada ibu sectio caesarea salah satunya adalah dengan pijat oksitosin. Pijat oksitosin adalah tindakan pemijatan yang dilakukan sepanjang tulang vertebra sampai costae kelima, keenam dan merupakan usaha untuk merangsang hormon prolaktin dan oksitosin setelah melahirkan $^{13}$. Dari pengertian tersebut maka peneliti memilih memberikan pijat oksitosin untuk lebih mengetahui keefektifan kecepatan pengeluaran kolostrum pada ibu post partum sectio caesar.

Cara kerja pijat oksitosin dalam mempengaruhi pengeluaran kolostrum adalah dengan memberikan stimulus pada vertebra sampai costa 5-6, sehingga meningkatkan rangsangan hipofise posterior untuk mengeluarkan hormon oksitosin, oksitosin selanjutnya akan merangsang kontraksi sel mioepitel di payudara untuk penyemprotan air susu ${ }^{14}$. Rangsangan ini kemudian dilanjutkan ke hipotalamus melalui medulla spinalis, sehingga hipotalamus akan menekan pengeluaran faktor yang menghambat sekresi prolaktin dan sebaliknya merangsang pengeluaran faktor yang memicu sekresi prolaktin, selanjutnya akan merangsang hipofise anterior sehingga keluar prolaktin dan selanjutnya hormon prolaktin akan merangsang sel-sel alveoli yang berfungsi untuk membuat air susu $^{3}$. Pengeluaran kolostrum pada ibu sectio caesarea akan lebih cepat, sehingga ibu mampu untuk memberikan kolostrum sesegera mungkin pada bayi baru lahir (BBL). Penelitian ini mengembangkan teknik pijat oksitosin untuk upaya meningkatkan pengeluaran kolostrum sebagai salah satu cara untuk meningkatkan kesehatan bayi dan memberikan dukungan pada ibu sectio caesare untuk keberlanjutan dalam memberikan ASI secara eksklusif bagi buah hatinya sampai usia bayi enam bulan. 


\section{METODE PENELITIAN}

Penelitian ini bersifat quasi experiment dengan pendekatan rancangan penelitian post test only design. Penelitian ini dilakukan dengan mengobservasi waktu pengeluaran kolostrum pada ibu responden sesudah diberi perlakuan (post test) pijat oksitosin pada kelompok perlakuan dan observasi post test waktu pengeluaran kolostrum pada ibu responden yang tidak diberi perlakuan pada kelompok kontrol. Populasi dalam penelitian ini adalah semua ibu post partum sectio caesar 12 jam pertama yang belum mengeluarkan kolostrum di Rumah Sakit Marinir Ewa Pangalila Surabaya pada bulan April-Mei 2015 sebanyak 22 responden.

Populasi pada penelitian ini adalah ibu post partum sectio caesar 12 jam pertama yang belum mengeluarkan kolostrum. Kriteria inklusi dalam penelitian ini adalah Ibu post partum sectio caesar yang belum mendapatkan terapi pijat oksitosin. sedangkan Kriteria eksklusi dalam penelitian ini adalah: Ibu post partum SC yang sudah mengeluarkan kolostrum, Ibu yang menjalani pemeriksaan dengan menggunakan zat radioaktif, Ibu menderita HIV positif dan belum mendapat terapi ARV. Sampel pada penelitian ini adalah sebagian ibu post partum sectio caesar yang ada di Rumah Sakit Marinir Ewa Pangalila Surabaya dengan jumlah 20 ibu pada bulan April-Mei 2015. Variabel bebas (Independent) dalam penelitian ini adalah pijat oksitosin. Variabel terikat dalam penelitian ini adalah waktu pengeluaran kolostrum pada ibu post partum sectio caesar.

\section{HASIL PENELITIAN}

\section{Karakteristik Responden}

Merupakan gambaran tentang karakteristik responden yang meliputi usia, pendidikan terakhir, pekerjaan ibu, riwayat SC, status gizi ibu selama kehamilan, status kesehatan ibu pasca persalinan, pengalaman menyusui sebelumnya, perawatan payudara selama kehamilan, yang menemani ibu selama masa awal menyusui.

Tabel 1. Karakteristik Responden Berdasarkan Usia Ibu Post Partum Sectio Caesar Kelompok Kontrol dan Perlakuan

\begin{tabular}{lcccc}
\hline Usia & \multicolumn{2}{c}{ Kontrol } & \multicolumn{2}{c}{ Perlakuan } \\
\cline { 2 - 5 } & $\mathrm{f}$ & $\%$ & $\mathrm{f}$ & $\%$ \\
\hline $\begin{array}{l}<21 \\
\text { tahun }\end{array}$ & 4 & 40.0 & 4 & 40.0 \\
$\begin{array}{l}21-30 \\
\text { tahun }\end{array}$ & 2 & 20.0 & 1 & 10.0 \\
$\begin{array}{l}31-40 \\
\text { tahun } \\
>40 \\
\text { tahun }\end{array}$ & 4 & 40.0 & 5 & 50.0 \\
\hline Total & 10 & 100.0 & 10 & 100.0 \\
\hline
\end{tabular}

Tabel 1 menunjukkan bahwa pada kelompok kontrol ibu post partum sectio caesar usia $<21$ tahun sebanyak 4 orang (40.0\%), usia 31-40 sebanyak 4 orang (40.0\%), usia 21-30 tahun sebanyak 2 orang (20.0\%). Pada kelompok perlakuan ibu post partum sectio caesar usia 31-40 tahun sebanyak 5 orang $(50.0 \%)$, usia < 21 tahun sebanyak 4 orang $(40.0 \%)$, usia 21-30 tahun sebanyak 1 orang (10.0\%).

Tabel 2. Karakteristik Responden Berdasarkan Pendidikan Ibu Post Partum Sectio Caesar Kelompok Kontrol dan Perlakuan 


\begin{tabular}{lcccc}
\hline Pendidikan & \multicolumn{2}{c}{ Kontrol } & \multicolumn{2}{c}{ Perlakuan } \\
\cline { 2 - 5 } & f & $\%$ & f & $\%$ \\
& & & & \\
\hline Tidak Sekolah & - & 0.0 & - & 0.0 \\
SD & - & 0.0 & - & 0.0 \\
SMP & 2 & 20.0 & 1 & 10.0 \\
SMA & 7 & 70.0 & 6 & 60.0 \\
Perguruan & 1 & 10.0 & 3 & 30.0 \\
Tinggi & & & & \\
\hline Total & 10 & 100.0 & 10 & 100. \\
& & & & 0 \\
\hline
\end{tabular}

Tabel 2 menunjukkan bahwa pada kelompok kontrol ibu post partum sectio caesar pendidikan terakhir SMA sebanyak 7 orang $(70.0 \%)$, pendidikan terakhir SMP sebanyak 2 orang (20.0\%), pendidikan terakhir perguruan tinggi sebanyak 1 orang $(10.0 \%)$. Pada kelompok perlakuan ibu post partum sectio caesar pendidikan terakhir SMA sebanyak 6 orang $(60.0 \%)$, pendidikan terakhir perguruan tinggi sebanyak 3 orang $(30.0 \%)$, pendidikan terakhir SMP sebanyak 1 orang $(10.0 \%)$.

Tabel 3. Karakteristik Responden Berdasarkan Pekerjaan Ibu Post Partum Sectio Caesar Kelompok Kontrol dan Perlakuan

\begin{tabular}{lllll}
\hline \multirow{2}{*}{ Pekerjaan } & \multicolumn{2}{c}{ Kontrol } & \multicolumn{2}{c}{$\begin{array}{c}\text { Perlakua } \\
\text { n }\end{array}$} \\
\cline { 2 - 6 } & & & & \multicolumn{2}{c}{$\mathrm{n}$} \\
\hline PNS & $\%$ & $\mathrm{f}$ & $\%$ \\
TNI/POLRI & - & 0.0 & - & 0.0 \\
Swasta/Wirausaha & 5 & 50.0 & 4 & 40.0 \\
Ibu Rumah Tangga & 5 & 50.0 & 5 & 50.0 \\
\hline Total & 1 & 100. & 1 & 100. \\
& 0 & 0 & 0 & 0 \\
\hline
\end{tabular}

Tabel 3 menunjukkan bahwa pada kelompok kontrol ibu post partum sectio caesar pekerjaan sebagai ibu rumah tangga sebanyak 5 orang (50.0\%), pekerjaan sebagai swasta/wirausaha sebanyak 5 orang (50.0\%). Pada kelompok perlakuan ibu post partum sectio caesar pekerjaan sebagai ibu rumah tangga sebanyak 5 orang (50.0\%), pekerjaan sebagai swasta/wirausaha sebanyak 4 orang (40.0\%), pekerjaan sebagai TNI/POLRI sebanyak 1 orang $(10.0 \%)$.

Tabel 4. Karakteristik Responden Berdasarkan Riwayat SC Ibu Post Partum Sectio Caesar Kelompok Kontrol dan Perlakuan

\begin{tabular}{lrrrr}
\hline $\begin{array}{l}\text { Riway } \\
\text { at SC }\end{array}$ & \multicolumn{2}{c}{ Kontrol } & \multicolumn{2}{c}{ Perlakuan } \\
\cline { 2 - 5 } & & $\mathrm{f}$ & $\%$ & \multicolumn{2}{c}{$\mathrm{f}$} & $\%$ \\
\hline $\begin{array}{l}\text { Sudah } \\
\text { Belu }\end{array}$ & 1 & 10.0 & 2 & 20.0 \\
m & & 90.0 & 8 & 80.0 \\
\hline Total & 10 & 100.0 & 10 & 100.0 \\
\hline
\end{tabular}

Tabel 4 menunjukkan bahwa pada kelompok kontrol ibu post partum sectio caesar yang belum pernah menjalani sectio caesar sebelumnya sebanyak 9 orang $(90.0 \%)$, dan yang sudah pernah menjalani sectio caesar sebelumnya sebanyak 1 orang $(10.0 \%)$. Pada kelompok perlakuan ibu post partum sectio caesar yang belum pernah menjalani sectio caesar sebelumnya sebanyak 8 orang (80.0\%), dan yang sudah pernah menjalani sectio caesar sebelumnya sebanyak 2 orang (20.0\%).

Tabel 5. Karakteristik Responden Berdasarkan Jenis Anastesi Ibu Post Partum Sectio Caesar Kelompok Kontrol dan Perlakuan

\begin{tabular}{|c|c|c|}
\hline \multirow{2}{*}{$\begin{array}{l}\text { Jenis } \\
\text { Anastesi }\end{array}$} & Kontrol & Perlakuan \\
\hline & $\%$ & $\%$ \\
\hline
\end{tabular}




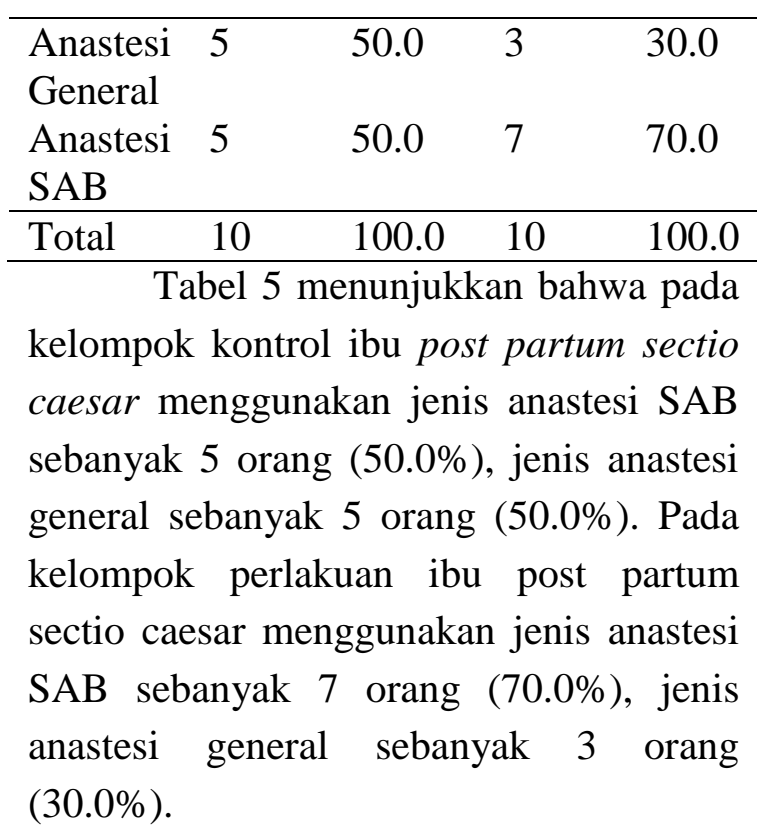

Tabel 6. Karakteristik Responden Berdasarkan Status Gizi Kehamilan Ibu Post Partum Sectio Caesar Kelompok Kontrol dan Perlakuan

\begin{tabular}{|c|c|c|c|c|}
\hline \multirow{2}{*}{$\begin{array}{l}\text { Status } \\
\text { Gizi }\end{array}$} & \multicolumn{2}{|c|}{ Kontrol } & \multicolumn{2}{|c|}{ Perlakuan } \\
\hline & $f$ & $\%$ & $\mathrm{f}$ & $\%$ \\
\hline Lebih & 1 & 10.0 & 2 & 20.0 \\
\hline Cukup & 6 & 60.0 & 8 & 80.0 \\
\hline Kurang & 3 & 30.0 & - & 0.0 \\
\hline Total & 10 & 100.0 & 10 & 100.0 \\
\hline
\end{tabular}

Tabel 6 menunjukkan bahwa pada kelompok kontrol ibu post partum sectio caesar mempunyai status gizi cukup sebanyak 6 orang $(60.0 \%)$, status gizi kurang sebanyak 3 orang (30.0\%), status gizi lebih sebanyak 1 orang (10.0\%). Pada kelompok perlakuan ibu post partum sectio caesar mempunyai status gizi cukup sebanyak 8 orang $(80.0 \%)$, status gizi lebih sebanyak 2 orang $(20.0 \%)$.

Tabel 7. Karakteristik Responden Berdasarkan Status Kesehatan Pasca Persalinan Ibu Post Partum Sectio Caesar Kelompok Kontrol dan Perlakuan

\begin{tabular}{|c|c|c|c|c|}
\hline \multirow{2}{*}{$\begin{array}{l}\text { Status } \\
\text { Kesehatan }\end{array}$} & \multicolumn{2}{|c|}{ Kontrol } & \multicolumn{2}{|c|}{ Perlakuan } \\
\hline & $\mathrm{f}$ & $\%$ & $\mathrm{f}$ & $\%$ \\
\hline Baik & 6 & 60.0 & 8 & 80.0 \\
\hline $\begin{array}{l}\text { Kurang } \\
\text { Baik }\end{array}$ & 4 & 40.0 & 2 & 20.0 \\
\hline Total & 10 & 100.0 & 10 & 100.0 \\
\hline
\end{tabular}

Tabel 7 menunjukkan bahwa pada kelompok kontrol ibu post partum sectio caesar mempunyai status kesehatan pasca persalinan baik sebanyak 6 orang $(60.0 \%)$, status kesehatan kurang baik sebanyak 4 orang $(40.0 \%)$. Pada kelompok perlakuan ibu post partum sectio caesar mempunyai status kesehatan pasca persalinan baik sebanyak 8 orang $(80.0 \%)$, status kesehatan kurang baik sebanyak 2 orang $(20.0 \%)$.

Tabel 8. Karakteristik Responden Berdasarkan Status Kesehatan Pasca Persalinan Ibu Post Partum Sectio Casear Kelompok Kontrol dan Perlakuan di Rumah Sakit Marinir

\begin{tabular}{ccccc}
\hline Pengalaman & \multicolumn{2}{c}{ Kontrol } & \multicolumn{2}{c}{ Perlakuan } \\
\cline { 2 - 5 } Menyusui & $\mathrm{f}$ & $\%$ & $\mathrm{f}$ & $\%$ \\
& & & & \\
\hline Sudah & 1 & 10.0 & 6 & 60.0 \\
Belum & 9 & 90.0 & 4 & 40.0 \\
\hline Total & 10 & 100.0 & 10 & 100.0 \\
\hline
\end{tabular}

Tabel 8 menunjukkan bahwa pada kelompok kontrol perlakuan ibu post partum sectio caesar belum berpengalaman menyusui sebanyak 9 orang $(90.0 \%)$, sudah berpengalaman menyusui sebanyak 1 orang (10.0\%). Pada kelompok perlakuan ibu post partum sectio caesar sudah berpengalaman menyusui sebanyak 6 orang $(60.0 \%)$, belum berpengalaman menyusui sebanyak 4 orang $(40.0 \%)$. 
Tabel 9. Karakteristik Responden Berdasarkan Perawatan Payudara selama Kehamilan Ibu Post Partum Sectio Caesar Kelompok Kontrol dan Perlakuan

\begin{tabular}{lrrrr}
\hline Perawatan & \multicolumn{2}{c}{ Kontrol } & \multicolumn{2}{c}{ Perlakuan } \\
\cline { 2 - 5 } Payudara & f & $\%$ & f & $\%$ \\
& & & & \\
\hline Melakukan & 3 & 40.0 & 7 & 70.0 \\
Belum & 7 & 60.0 & 3 & 30.0 \\
Melakukan & & & & \\
\hline Total & 10 & 100.0 & 10 & 100.0 \\
\hline
\end{tabular}

Tabel 9 menunjukkan bahwa pada kelompok kontrol ibu post partum sectio caesar yang tidak melakukan perawatan payudara sebanyak 7 orang $(70.0 \%)$, yang melakukan perawatan payudara sebanyak 3 orang (30.0\%). Pada kelompok perlakuan ibu post partum sectio caesar yang melakukan perawatan payudara sebanyak 7 orang $(70.0 \%)$, yang tidak melakukan perawatan payudara sebanyak 3 orang $(30.0 \%)$.

Tabel 10. Karakteristik Responden Berdasarkan Dukungan Keluarga Post Partum Sectio Caesar Kelompok Kontrol dan Perlakuan

\begin{tabular}{lllllc}
\hline Dukungan & \multicolumn{2}{c}{ Kontrol } & \multicolumn{2}{c}{ Perlakuan } \\
\cline { 2 - 6 } Keluarga & $\mathrm{f}$ & $\%$ & $\mathrm{f}$ & $\%$ \\
& & & & \\
\hline Suami & 3 & 30.0 & 8 & 80.0 \\
Orang & 6 & 60.0 & 2 & 20.0 \\
Tua & & & & \\
Lainnya & 1 & 10.0 & - & 0.0 \\
\hline Total & 10 & 100.0 & 10 & 100.0 \\
\hline
\end{tabular}

Berdasarkan Tabel 10 tersebut menunjukkan bahwa pada kelompok kontrol ibu post partum sectio caesar yang dukungan keluarga dalam Menyusui oleh suami sebanyak 6 orang $(60.0 \%)$, dukungan keluarga oleh orang tua sebanyak 3 orang $(30.0 \%)$, dukungan keluarga lainnya sebanyak 1 orang (10.0\%).Pada kelompok perlakuan ibu post partum sectio caesar yang dukungan keluarga dalam proses menyusui oleh suami sebanyak 8 orang $(80.0 \%)$, dukungan keluarga oleh orang tua sebanyak 2 orang (20.0\%).

Tabel 11. Karakteristik Responden Berdasarkan Lama Waktu

\begin{tabular}{lcc}
\hline $\begin{array}{c}\text { Waktu } \\
\text { Pengeluaran } \\
\text { Kolostrum }\end{array}$ & $\mathrm{f}$ & $\%$ \\
\hline$<24$ jam & - & 0.0 \\
$24-36$ jam & 3 & 30.0 \\
$>48$ jam & 7 & 70.0 \\
\hline Total & 10 & 100.0 \\
\hline Berdasarkan & Tabel & tersebut \\
menunjukkan bahwa lama & waktu \\
pengeluaran kolostrum pada kelompok \\
kontrol ibu post partum sectio caesar \\
selama <24 jam sebanyak 0 orang (0.0\%), \\
waktu pengeluaran kolostrum selama 24- \\
36 jam sebanyak 3 orang (30.0\%), waktu \\
pengeluaran kolostrum selama >48 jam \\
sebanyak 7 orang (70.0\%).
\end{tabular}

Tabel 12. Karakteristik Responden Berdasarkan Lama Waktu Pengeluaran Kolostrum Pada Kelompok Perlakuan

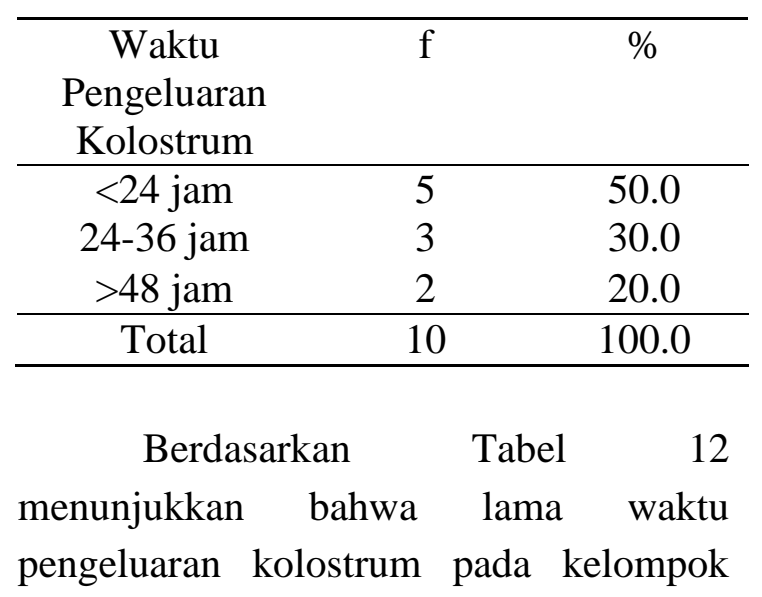


perlakuan ibu post partum sectio caesar selama $<24$ jam sebanyak 5 orang (50.0\%), waktu pengeluaran kolostrum selama 24-36 jam sebanyak 3 orang (30.0\%), waktu pengeluaran kolostrum selama $>48$ jam sebanyak 2 orang $(20.0 \%)$.

Tabel 13. Karakteristik Responden Berdasarkan Pengaruh Pijat Oksitosin terhadap Waktu Pengeluaran Kolostrum

\begin{tabular}{lccc}
\hline & $\mathrm{N}$ & Median & P Value \\
\hline Perlakuan & 10 & 1,70 & $\mathrm{p}=$ \\
Kontrol & 10 & 2,70 & 0,026
\end{tabular}

Tabel 13 menunjukkan bahwa pengaruh pijat oksitosin terhadap waktu pengeluaran kolostrum pada ibu post partum sectio caesar di Rumah Sakit Marinir Surabaya dan didapatkan data bahwa dari 20 orang responden ibu post partum sectio caesar. Menyatakan bahwa hasil uji statistik Wilcoxon menunjukkan hasil $p=0,026<0,05$, bermakna Ho ditolak sehingga terdapat pengaruh pijat oksitosin terhadap waktu pengeluaran kolostrum di RS Marinir Ewa Pangalila Surabaya.

\section{PEMBAHASAN}

Waktu pengeluaran kolostrum pada kelompok kontrol ibu post partum sectio caesar yang telah diberikan pijat oksitosin di Rumah Sakit Marinir Ewa Pangalila Surabaya

Secara umum hasil penelitian di Rumah Sakit Marinir Ewa Pangalila Surabaya menunjukkan bahwa responden ibu pada kelompok kontrol yang pengeluaran kolostrum selama 24-36 jam sebanyak 3 orang $(30.0 \%)$ dan selama $>48$ jam sebanyak 7 orang (70.0\%). Data yang didapatkan di Rumkitmar Ewa Pangalila Surabaya, responden yang melakukan perawatan payudara pada masa kehamilan sebanyak 3 orang (30.0\%). Perawatan payudara sebaiknya dilakukan selama masa-masa akhir kehamilan, terutama kehamilan bulan ketujuh (kehamilan trimester ketiga) ${ }^{1}$. Menurut ${ }^{15}$ pada trimester ketiga kehamilan laktogen plasenta mulai merangsang untuk pembuatan kolostrum, keaktifan dari rangsangan hormon-hormon terhadap pengeluaran air susu mempengaruhi kecepatan dalam proses laktasi. Berdasarkan data penelitian tersebut peneliti berasumsi bahwa perawatan payudara yang dilakukan sejak masa kehamilan membantu dalam kecepatan proses laktasi yang sudah mulai berproses didalam tubuh ibu, terutama pada trimester ketiga hormon-hormon bekerja dalam mempersiapkan ASI bagi bayi setelah lahir, perawatan payudara yang dilakukan oleh para ibu pada masa kehamilan bekerja dengan merangsang hormon-hormon yang mempengaruhi pembentukan ASI selama kehamilan yaitu progesteron, estrogen, prolaktin, oksitosin dan HPL, sehingga proses pembentukan ASI lebih produktif dan waktu pengeluaran kolostrum lebih cepat.

Hasil menunjukkan 3 orang $(30.0 \%)$ responden yang melakukan perawatan payudara, 2 orang $(20.0 \%)$ diantaranya mendapat dukungan keluarga dalam hal ini suami pada saat proses awal menyusui. Suami (ayah) yang mendukung ASI, 98 persen ASI eksklusif berhasil, sedangkan ayah yang tidak mendukung ASI keberhasilannya hanya 26 persen saja $^{4}$. Menurut ${ }^{15}$ peran suami pada ibu menyusui sangat berpengaruh dalam 
meningkatkan hormon oksitosin, yang harus diketahui bahwa kerja hormon oksitosin sangat dipengaruhi oleh pikiran ibu (positif atau negatif), pikiran ibu akan memperlancar pengeluaran hormon ini, demikian sebaliknya. Berdasarkan data penelitian diatas peneliti berasumsi dukungan keluarga terutama suami dapat mempengaruhi perasaan dan pikiran ibu yang mempengaruhi kerja hormon oksitosin, perasaan nyaman dan tenang yang dirasakan ibu dapat meningkatkan stimulasi hipofise posterior untuk mengeluarkan hormon oksitosin yang dapat merangsang sel alveoli untuk memproduksi ASI sehingga waktu pengeluaran kolostrum lebih cepat. Responden dengan waktu pengeluaran kolostrum 24-36 jam sebanyak 3 orang (30.0\%) namun 1 orang (10.0\%) responden yang tidak melakukan perawatan payudara memiliki status gizi lebih saat masa kehamilan. Makanan yang dikonsumsi ibu menyusui sangat berpengaruh terhadap produksi $\mathrm{ASI}^{16}$. Apabila makanan yang ibu makan mengandung cukup gizi dan pola makan yang teratur, maka produksi ASI akan berjalan dengan lancar. Berdasarkan data penelitian diatas peneliti berasumsi bahwa ibu yang memiliki status gizi kurang, produksi ASI dapat menurun. Hal ini disebabkan nutrisi maupun vitamin yang dikonsumsi ibu kurang dapat terserap dalam tubuh untuk proses laktasi.

Responden dengan waktu pengeluaran kolostrum $>48$ jam sebanyak 7 orang $(70.0 \%)$. Data yang didapatkan di Rumkitmar Ewa Pangalila Surabaya, responden yang tidak melakukan perawatan payudara pada masa kehamilan sebanyak 7 orang $(60.0 \%)$. Perawatan payudara sebaiknya dilakukan sejak selama masa-masa akhir kehamilan, terutama kehamilan bulan ketujuh (kehamilan trimester ketiga) ${ }^{1}$. Penelitian yang dilakukan oleh ${ }^{17}$ tentang faktor determinan produksi ASI pada ibu menyusui di Puskesmas Talaga Jaya Gorontalo mendapatkan hasil bahwa dengan tidak melakukan perawatan payudara memberi kemungkinan untuk mengalami produksi ASI kurang yang dinilai melalui $\operatorname{Exp}(B)=3,433$ kali lebih besar dibandingkan dengan yang melakukan perawatan payudara. Berdasarkan penelitian diatas peneliti berasumsi bahwa perawatan payudara yang tidak dilakukan sejak masa kehamilan menimbulkan hambatan produksi ASI hal ini disebabkan kurang adanya stimulus yang dapat merangsang hormon-hormon yang mempengaruhi pembentukan ASI selama kehamilan yaitu progesteron, estrogen, prolaktin, oksitosin dan HPL, sehingga proses pembentukan ASI kurang produktif dan pengeluaran ASI mengalami keterlambatan. sebanyak 2 orang $(20.0 \%)$ responden yang tidak mendapat dukungan keluarga namun mendapat jenis anastesi general saat persalinan sectio caesar. Ibu yang melahirkan dengan cara operasi caesar $(C$ sectomi) seringkali sulit menyusui bayinya segera setelah ia lahir ${ }^{18}$. Terutama jika ibu diberikan anastesia umum. Ibu relatif tidak sadar untuk dapat mengurus bayinya di jam pertama setelah bayi lahir. Kondisi luka operasi di bagian perut relatif membuat proses menyusui sedikit terhambat. Sementara itu, bayi mungkin mengantuk dan tidak responsif untuk menyusu, terutama jika ibu mendapatkan obat-obatan penghilang rasa sakit sebelum 
operasi. Beberapa peneliti menyimpulkan bahwa proses melahirkan dengan caesar akan menghambat terbentuknya produksi ASI. Meskipun demikian, menyusui sesering mungkin setelah proses kelahiran dengan caesar akan meminimalisasi masalah-masalah tersebut. Bahkan beberapa ibu yang melahirkan dengan caesarea memiliki produksi ASI yang melimpah.

Berdasarkan data penelitian diatas peneliti berasumsi bahwa jenis anastesi general bekerja dengan melumpuhkan sistem saraf pusat secara keseluruhan sehingga ibu yang menjalani anastesi tersebut mengalami kesulitan dalam pemberian ASI pertama dikarenakan ibu masih dalam pengaruh obat anastesi, dalam hal ini keterlambatan pengeluaran kolostrum akan terjadi karena ibu tidak mendapat rangsangan dari luar yang dapat menstimulasi hipofise posterior dengan begitu secara berkelanjutan akan mengalami keterlambatan pada produksi hormon prolaktin yang berpengaruh dalam proses pembentukan ASI. Kecepatan pengeluaran kolostrum pada ibu post partum sectio caesar memberikan pengaruh terhadap kecepatan pemberian nutrisi awal untuk bayi baru lahir, kolostrum yang banyak mengandung protein dan antibodi tentu sangat dibutuhkan bayi pada masa awal kehidupannya karena sistem immunitas bayi masih sangat retan terhadap suasana lingkungan disekitarnya, selain itu pada anastesi general biasanya ibu mengalami lebih lama mobilisasi dibandingkan dengan ibu anastesi SAB.

Waktu pengeluaran kolostrum pada kelompok perlakuan ibu post partum sectio caesar yang telah diberikan pijat oksitosin di Rumah Sakit Marinir Ewa Pangalila Surabaya

Secara umum hasil penelitian di Rumah Sakit Marinir Ewa Pangalila Surabaya. responden ibu pada kelompok perlakuan yang pengeluaran kolostrum selama <24 jam sebanyak 5 orang (50.0\%), selama 24-36 jam sebanyak 3 orang $(10.0 \%)$, dan selama $>48$ jam sebanyak 2 orang (20.0\%). Data yang didapatkan di Rumkitmar Ewa Pangalila Surabaya, responden yang melakukan perawatan payudara pada masa kehamilan sebanyak 5 orang (50.0\%). Perawatan payudara sebaiknya dilakukan sejak selama masa-masa akhir kehamilan, terutama kehamilan bulan ketujuh (kehamilan trimester ketiga) ${ }^{1}$. Pada trimester ketiga kehamilan laktogen plasenta mulai merangsang untuk pembuatan kolostrum, keaktifan dari rangsangan hormon-hormon terhadap pengeluaran air susu mempengaruhi kecepatan dalam proses laktasi ${ }^{15}$.

Berdasarkan data penelitian diatas peneliti berasumsi bahwa perawatan payudara yang dilakukan sejak masa kehamilan membantu dalam kecepatan proses laktasi yang sudah mulai bekerja didalam tubuh ibu, terutama pada trimester ketiga hormon-hormon bekerja dalam mempersiapkan ASI bagi bayi setelah lahir, perawatan payudara yang dilakukan oleh para ibu pada masa kehamilan bekerja dengan merangsang hormon-hormon yang mempengaruhi pembentukan ASI selama kehamilan yaitu progesteron, estrogen, prolaktin, oksitosin dan HPL, sehingga proses pembentukan ASI lebih produktif dan waktu pengeluaran kolostrum lebih cepat. 
Sebanyak 5 orang $(50.0 \%)$ pada kelompok perlakuan dengan waktu pengeluaran kolostrum $<24$ jam yang sudah melakukan perawatan payudara juga mendapat dukungan keluarga dalam hal ini dukungan suami pada proses awal menyusui.

Berdasarkan data penelitian diatas peneliti berasumsi bahwa dukungan keluarga untuk responden hanya didapatkan dari orang tua sehingga kurang memberikan nyaman perasaan dan pikiran ibu akibatnya kerja hormon oksitosin berkurang sehingga waktu pengeluaran kolostrum lebih terlambat. Kecepatan pengeluaran kolostrum pada ibu post partum sectio caesar memberikan pengaruh terhadap kecepatan pemberian nutrisi awal untuk bayi baru lahir, kolostrum yang banyak mengandung protein dan antibodi tentu sangat dibutuhkan bayi pada masa awal kehidupannya karena sistem immunitas bayi masih sangat retan terhadap suasana lingkungan disekitarnya.

Pengaruh pijat oksitosin terhadap waktu pengeluaran kolostrum pada ibu post partum sectio caesar di Rumah Sakit Marinir Ewa Pangalila Surabaya

Berdasarkan hasil penelitian yang dilakukan dari 20 orang responden di Rumah Sakit Marinir Ewa Pangalila Surabaya, didapatkan hasil dari analisa statistic non parametrik test 2 indepedence sample (uji wilcoxon) menyatakan bahwa hasil uji statistik wilcoxon menunjukkan hasil $\mathrm{p}=$ 0,026<0,05, bermakna Ho ditolak dan $\mathrm{H}_{1}$ diterima sehingga terdapat pengaruh pijat oksitosin terhadap waktu pengeluaran kolostrum di Rumah Sakit Marinir Ewa Pangalila Surabaya.

Pada ibu post partum sectio caesar yang dilakukan pijat oksitosin didapatkan hasil dari observasi waktu pengeluaran kolostrum lebih cepat <24 jam sebanyak 5 orang $(50.0 \%)$. Pijatan atau rangsangan pada tulang belakang, neurotransmitter akan merangsang medulla oblongata langsung mengirim pesan ke hypotalamus di hipofise posterior untuk mengeluarkan oksitosin yang menyebabkan buah dada mengeluarkan air susunya ${ }^{19}$. Pijatan di daerah tulang belakang ini juga akan merileksasikan ketegangan dan menghilangkan stres dan dengan begitu hormon oksitosin keluar dan akan membantu pengeluaran air susu ibu, dibantu dengan isapan bayi pada puting susu pada saat segera setelah bayi lahir dengan keadaan bayi normal.

Berdasarkan penelitian tersebut peneliti berasumsi bahwa adanya pengaruh pijat oksitosin terhadap waktu pengeluaran kolostrum dipengaruhi oleh perawatan payudara dan dukungan keluarga, yang bekerja dengan menstimulasi hormon oksitosin yang dihasilkan dari rasa nyaman, tenang, tidak mengalami stres sehingga tubuh dapat menstimulasi hipofise posterior untuk meningkatkan pengeluaran hormon oksitosin, saat oksitosin meningkat hipofise anterior terstimulasi untuk mengeluarkan hormon prolaktin yang dapat merangsang sel alveoli sehingga produksi ASI dapat meningkat.

\section{SIMPULAN}

Berdasarkan hasil penelitian yang dilakukan oleh peneliti di Rumah Sakit Marinir Ewa Pangalila Surabaya pada 
bulan April-Mei 2015 dapat di simpulkan bahwa sebagian besar ibu post partum sectio caesaria di Rumah Sakit Marinir Ewa Pangalila Surabaya yang tidak dilakukan pijat oksitosin mempunyai waktu pengeluaran kolostrum selama $>48$ jam. Sebagian besar ibu post partum sectio caesar di Rumah Sakit Marinir Ewa Pangalila Surabaya setelah dilakukan pijat oskitosin mempunyai waktu pengeluaran kolostrum selama $<24$ jam. Ada pengaruh pijat oksitosin terhadap waktu pengeluaran kolostrum pada ibu post partum sectio caesar.

\section{SARAN}

Perlu dilakukan penelitian lebih lanjut jangka waktu pemijatan oksitoksin terhadap waktu pengeluran kolostrum pada ibu post partum sectio caesaria dan letak pijatan yang tepat.

\section{REFERENSI}

Astutik, R.Y.2014. Payudara dan laktasi. Jakarta: Salemba Medika.

Chomaria, Nurul. 2013. Paduan Super Lengkap Kehamilan, Kelahiran \& Tumbuh Kembang Anak Bagi Muslimah. Surakarta: AHAD Books.

Depkes R.I., 2008. Profil Kesehatan Indonesia. Jakarta.

Desmawati. 2013. Penentu Kecepatan Pengeluaran Air Susu Ibu Setelah Sectio Caesar. Di akses pada aamat http://Jurnalkesmas.ui.id/index.php/k esmas/article/view/22. diunduh tanggal 15 Februari 2015 jam 19.48 WIB.

Deswani, K.2012. Paduan Praktik Klinik dan Laboratorium Keperawatan Maternitas. Jakarta: Salemba Medika.

Dewi,Vivian, N,\& Tri, S.2011. Asuhan Kebidanan Pada Ibu Nifas. Jakarta: Salemba Medika Elfidrin.

Ferial, Eddyman, W.2013. Biologi Reproduksi. Jakarta: Erlangga .
Guyton \& Hall.2007. Buku Ajar Fisiologi Kedokteran, Edisi 11. Jakarta: EGC.

Haryono, Rudi \& Sulis, S. 2014. Manfaat ASI Eksklusif untuk Buah Hati Anda.Yogyakarta: Gosyen Publishing.

Herry, Garna, Heda, M. D, \& Nata Prawira., 2005. Pedoman Diagnosa dan Terapi Ilmu Kesehatan Anaka Edisi 3.Bandung: Bagian Ilmu Kesehatan Anak Fakultas Kedokteran Universitas Padjajaran.

IDAI. 2010. Faktor Determinan Produksi ASI Pada Ibu Menyusui Puskesmas Talaga Jaya Kabupaten Gorontalo Provinsi Gorontalo. Jakarta: Badan Penebit IDAI InfodatinMaga,Iramaya. Di akses pada halaman http://jurnalmagamaya.ui.id.index.ph $\mathrm{p} / \mathrm{maga} /$ article /view.pdf.diunduh pada tanggal 7 juli 2015 pukul 15.00 WIB.

Maga,I, Buraerah, H. A,\& Andi,.Z.2015. Determinant Factors Breastmilk Production In Publik Health Centre Talaga Jaya Gorontalo Regency Gorontalo Province. Artikel Ilmiah. Gorontalo: Politeknik Kesehatan Gorontalo.

Prasetyono,D.S. 2009. ASI Ekslusif pengenalan, Praktik, dan Kemanfaatan-kemanfaatanya. Diva Press: Yogyakarta.

Riset Kesehatan Dasar (RISKESDAS). 2007. Jakarta: Badan Penelitian dan

Pengembangan Kesehatan, Departemen Kesehatan, Republik Indonesia.

Sherwood \& Lauralee.2011. Fisiologi Manusia Dari Sel ke Sistem (Human Physiology: From Cells to System). Jakarta: EGC.

Sukarni \& Wahyu.2013. Buku Ajar Keperawatan Maternitas. Yogyakarta: Nuha Medika.

Widuri, H. 2013. Cara mengelola asi eksklusif bagi ibu bekerja. Yogyakarta: Gosyen Publishing. 
Yaeni, M. 2013. Analisa Indikasi Dilakukan Persalinan sectio Caesarea Di Rsup Dr. Soeradjitirtonegoro Klaten. Artikel. Surkarta: Universitas Muhammadiyah Surakarta.

Yohmi, E. \& Roesli, U. 2008. Manajemen Laktasi. In: Ikatan Dokter Anak Indonesia. Bedah ASI. Jakarta: Balai penerbit FKUI. 